\title{
New Record of some red algal species (Rhodophyta) from Korea
}

\author{
So Young Jeong ${ }^{1}$, Boo Yeon Won ${ }^{1}$, Pil Joon Kang ${ }^{2}$, Jeong Chan Kang ${ }^{3}$, Myung Sook Kim ${ }^{3}$, Ki Wan Nam², \\ Tae Oh Cho ${ }^{1, *}$ \\ ${ }^{1}$ Department of Marine Life Science and Marine Bio Research Center, Chosun University, Gwangju 501-759, Korea \\ ${ }^{2}$ Department of Marine Biology, Pukyong National University, Pusan 608-737, Korea \\ ${ }^{3}$ Department of Biology and Research Institute for Basic Sciences, Jeju National University, Jeju 690-756, Korea
}

\begin{abstract}
Rhodophyta is one of major groups in the number of species and diversity of the marine algal flora. The occurrence of Korean 5 red algal species is reported for the first time on the list of Korean marine algal flora based on morphology: Ceramium pacificum, Cumathanmnion serrulatum, Gayliella fimbriata, Leptofauchea rhodymenioides, Sorella pulchra. Ceramium pacificum from Korea is recognized by complete cortication, many adventitious branches in a radial arrangement, 7-8 periaxial cells, and plant length of $1-2 \mathrm{~cm}$. Cumathanmnion serrulatum is characterized by cartilaginous single main axis with a prominent midrib, serrulate blade, many higher orders of bladelets on each blade, and tetrasporagia produced near the midrib acropetally and then outwardly. Gayliella fimbriata is featured by clavate gland cell and 5-7 periaxial cells. Leptofauchea rhodymenioides is characterized by erect with flattened, dichotomously branched fronds, 1-2 cortical cells loosely arranged, 2-3 cell medullar layers with large colourless cells. Sorella pulchrais recognized by short branches produced alternately pinnate manner from margins of axial, mostly polystromatic frond, and tetrasporangial sori on the center of branches.
\end{abstract}

Key words: Ceramium pacificum, Cumathanmnion serrulatum, Gayliella fimbriata, Korea, Leptofauchea rhodymenioides, Rhodophyta, Sorella pulchra

\section{INTRODUCTION}

Kang (1966) reported 403 species in the catalogue of Korean marine algal flora. Afterwards, many species have been added to the Korean algal inventory though monographic and floristic researches (Lee and Kang 1986, Lee 2008). Up to now, about 900 species have been recorded in the Korean marine algal flora (Boo and Ko 2012).

Rhodophyta is one of major groups in the number of species and diversity of the marine algal flora. It is attached to surfaces of rocks, ropes, or organisms, has various habitats from intertidal zone to subtidal region, and distributes in the world. Rhodophyta is a large assemblage of between 2,500 and 6,000 species in about 670 largely marine genera (Woelkerling 1990). In the list of Korean flora (Lee and Kang 2002), over 260 red algal species have been added after 247 red algal species reported by Kang (1966).

We collected 5 red algal species which are not listed on the Korean marine algal inventory. In this study, we report them as the first records from Korea based on morphological observations: Ceramium pacificum (Colins) Kylin; Cumathanmnion serrulatum (Harvey) M.J. Wynne \& G.W. Saunders; Gayliella fimbriata (Setchell \& N.L.Gardner) T.O. Cho \& S.M. Boo; Leptofauchea rhodymenioides W.R. Taylor; Sorella pulchra (Yamada) Yoshida \& Mikami. http://dx.doi.org/10.5141/ecoenv.2013.439

(1) \$ This is an Open Access article distributed under the terms of the Creative Commons Attribution Non-Commercial Licens (http://creativecommons.org/licenses/by-nc/3.0/) which permits unrestricted non-commercial use, distribution, and reproduction in any medium, provided the original work is properly cited.
Received 29 October 2013, Accepted 26 November 2013

*Corresponding Author

E-mail: tocho@chosun.ac.kr

Tel: +82-62-230-7161 


\section{METERIALS AND METHODS}

Plants were collected from the coasts of Korea. Taxonomic data were obtained from 5\% formalin/seawater solution-preserved specimens. Materials were dissected by hand section using pith stick and razor blade. Materials were observed microscopically and stained with $1 \%$ aqueous aniline blue acidified with $0.1 \%$ diluted $\mathrm{HCl}$. For permanent slides, the glycerin was exchanged with $20 \%$ corn syrup. Photomicrographs were taken by CCD camera (DMCe 5000, INS industry co. Ltd., Korea) and digital camera (D300s, Nikon, Tokyo, Japan; DP71, Olympus, Tokyo, Japan) attached to microscope (BX50, Olympus; BX51TRF, Olympus). Representative specimens examined in this study are deposited in the National Institute of Biological Resources, Ministry of Environment, Korea.

\section{RESULTS AND DISCUSSION}

\section{Ceramium pacificum (Collins) Kylin 1925. P. 61 (Fig. 1) \\ Korean name: 잔가지비단풀(신칭) \\ Taxonomic position: \\ Phylum Rhodophyta \\ Class Florideophyceae \\ Order Ceramiales \\ Family Ceramiaceae \\ Genus Ceramium}

Lectotype: Phykotheka Universalis 302 (FH).

Type locality: Monterey, California.

Specimens examined: KOSPAL 0000126301, PKNU 0000126302 (Jumunjin: 26 Oct 2012).

Habitat: Epiphytic on other algae.

Morphology: Thalli up to 1-2 cm high (Fig. 1A), epiphytic on other algae, dichotomously branched (Fig. 1B), pink to light red in color and have many adventitious branches in a radial arrangement. Branching interval 7-14 nodes. Apex inrolled (Fig. 1D). Cortication complete (Fig. 1C) with 7-8 periaxial cells (Fig. 1E). Cystocarps produced near the apical portion, and surrounded by 5-7 involucral branchlets (Fig. 1F).

Remarks: Ceramium pacificum was described from eastern Pacific as Ceramium rubrum var. pacificum by Collins (1889) and elevated to species level by Kylin (1925). Ceramium pacificum is recognized by complete cortication, many adventitious branches in a radial arrangement, and 6-7 periaxial cells (Kylin 1925, Cho et al. 2001). Our specimens are distinguished by many adventitious branches in a radial arrangement from the other Korean Ceramium speceis with complete cortication: $C$. boydenii, C. kondoi and C. japonicum. Our specimens agree well with $C$. pacificum although they have 7-8 periaxial cells and plant length of $1-2 \mathrm{~cm}$. Also, our specimens may be similar to $C$. washingtoniense which has been synonymized with C. pacificum. C. washingtoniense was distinguished from C. pacificum only by small sized plant length and colour (Kylin 1925, Cho et al. 2002). Considering these features, our specimens are referred to C. pacificum. This study shows that C. pacificum is distributed in both temperate regions of the west and east Pacific from Korea to Chile (Santelices 1989, Scagel et al. 1989, Cho et al. 2001).

Cumathanmnion serrulatum (Harvey) M. J. Wynne \& G. W. Saunders (Fig. 2)

Korean name: 복바닷잎(신칭)

Taxonomic position:

Phylum Rhodophyta

Class Florideophyceae

Order Ceramiales

Family Delesseriaceae

Genus Cumathanmnion

Lectotype: FH (Yoshida 1998: 971).

Type locality: Hakodate, Japan.

Specimens examined: CUK9259 (Sokcho: 1 Feb 2012).

Habitat: Epilithic on bed rock.

Morphology: Thalli up to 14-25 cm high, 0.1-0.2 cm wide (Fig. 2A), flat, erect, red in color, and attached to the substrate by a thick and circular holdfast (Fig. 2B). They have cartilaginous single main axis with a prominent midrib (Fig. 2C) and numerous microscopic veins, bearing series of unilaterally branches (Fig. 2F). Second-order blades usually 2-10 $\mathrm{cm}$ long, produced along the midrib of mother blades. Each blade has one to several bladelets by producing many higher orders of bladelets (Fig. 2D and 2E). Margin of blade serrulate and toothed (Fig. 2G and $2 \mathrm{H}$ ). Blades monostromatic to polystromatic (Fig. 2I-2K). In tetrasporic plants, tetrasporangia developed in sori on entire blades which lack midrib cortication, derived first from the lateral pericentral cells and later from cells of the second- and third- order rows, rarely from cortical cells (Fig. 2L). Tetrasporagia mature acropetally and then outwards from the midrib, producing 4-7 tetrasporangia across the blade. Mature tetrasporangia 24.5-22.9 $\mu \mathrm{m}$ in diameter, spherical, and tetrahedral (Fig. 2M).

Remarks: This species was firstly described by Harvey (1857) as Delesseria serrulata from Hakodate, Japan. Wynne and Saunders (2012) transferred it into the genus Cumathamnion based on molecular and morphological data from the materials collected from California, USA. 

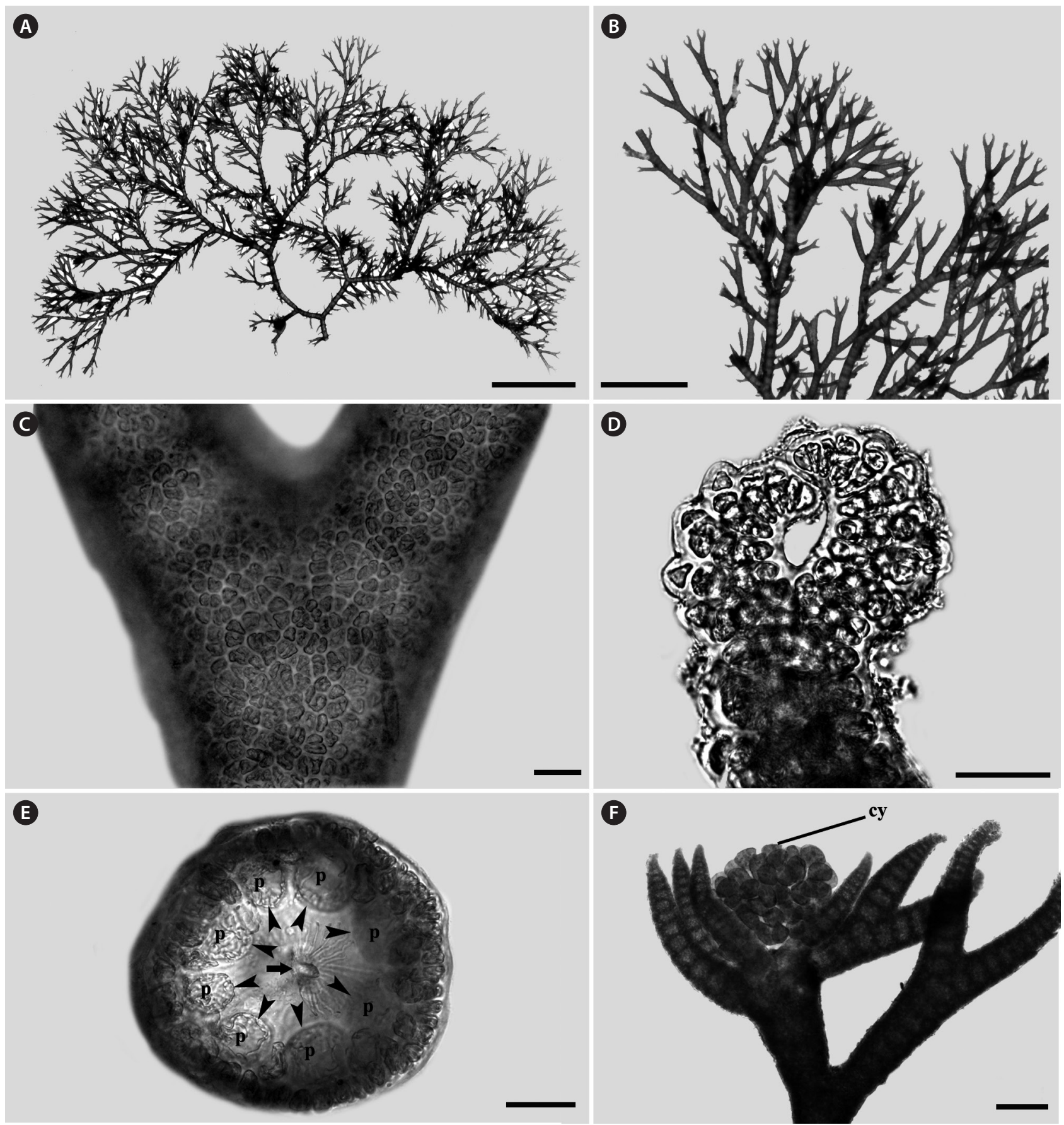

Fig. 1. Ceramium pacificum from Jumunjin, Korea. (A) Female plant with numerous branchlets. (B) Details of branches. (C) Branching point with complete cortication. (D) Apical region. (E) Axial cell (arrow) with 7-8 pericentral cells (arrowheads, p) in transverse section. (F) Mature cystocarp (cy). Scale bars represent: $A, 5 \mathrm{~mm} ; \mathrm{B}, 2 \mathrm{~mm} ; \mathrm{C}, 30 \mu \mathrm{m} ; \mathrm{D}, \mathrm{E}, 40 \mu \mathrm{m} ; \mathrm{F}, 200 \mu \mathrm{m}$.

Cumathanmion serrulatum is recognized by cartilaginous single main axis with a prominent midrib, serrulate and toothed blade, many higher orders of bladelets on each blade (Harvey 1857, Wynne and Daniels 1966, Wynne and Saunders 2012). We collected this species grow- ing on rock at intertidal zone from Sokcho in the eastern coasts of Korea. Our morphological observations are well agreed with the description of Harvey (1857) and Wynne and Saunders (2012). We add this species as Cumathamnion serrulatum in list of Korean algal flora. 

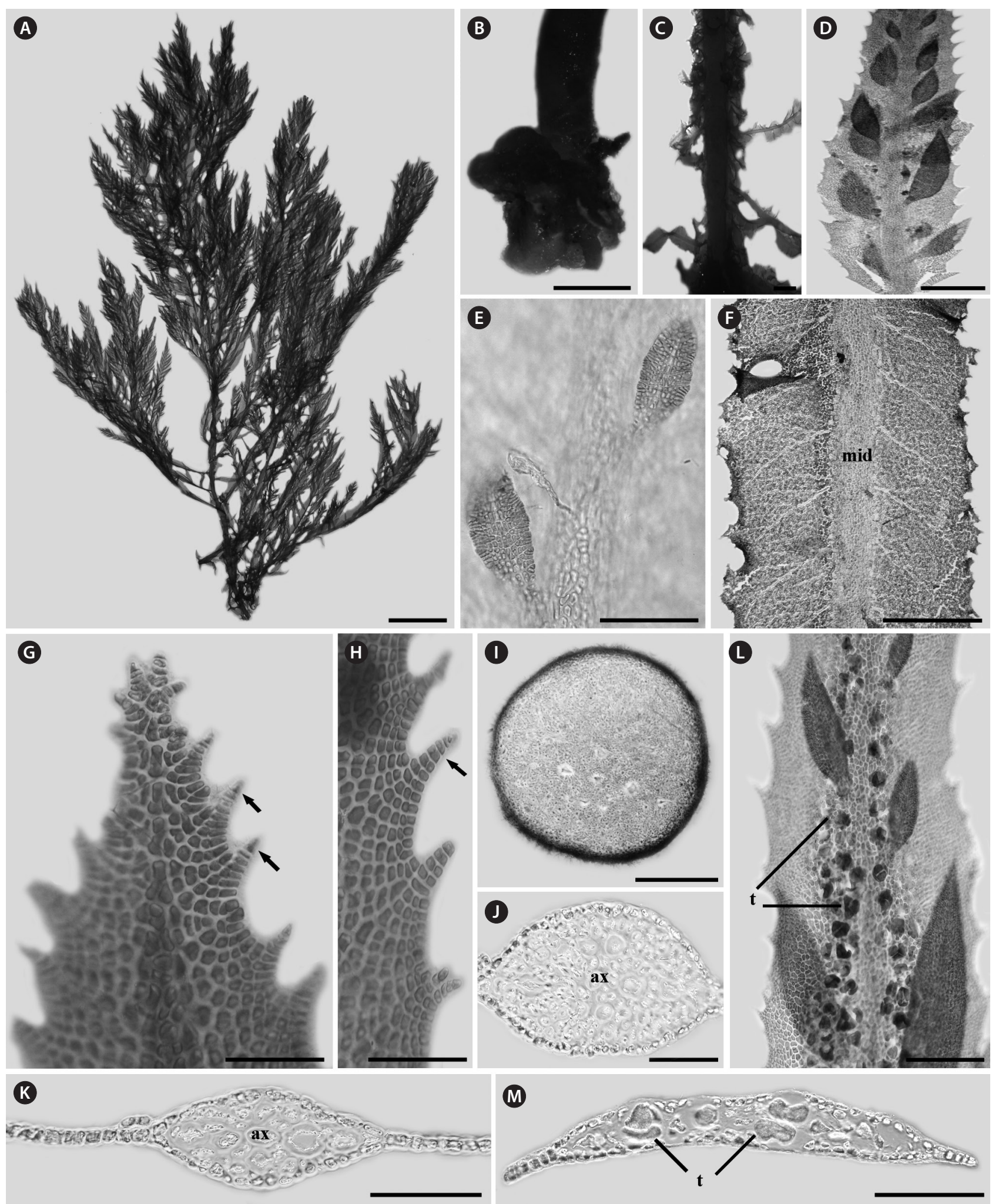

Fig. 2. Cumathamnion serrulatum from Sokcho, Korea. (A) Vegetative plant. (B) Holdfast. (C) Lower part of thallus. (D-E) Upper part of thallus showing alternate branching patterns and many higher order bladelets. (F) Middle part of thallus with midrib (mid) and lateral veins on blade. (G-H) Apical region of thallus showing serrulate margin (arrows). (I) Cross section view near holdfast. (J) Cross section view of secondary axis with axial cell (ax). (K) Cross section view of tertiary blade with axial cell (ax). (L) Tetrasporangial plant with tetrasporangia (t) produced on lateral pericentral cells. (M) Cross section view of tetrasporangial thallus with tetrasporangia (t). Scale bars represent: A, $2 \mathrm{~cm} ; B, 3 \mathrm{~mm} ; \mathrm{C}, 2 \mathrm{~mm} ; \mathrm{D}, \mathrm{F}, \mathrm{I}, 500 \mu \mathrm{m} ; \mathrm{E}, \mathrm{J}, \mathrm{K}, \mathrm{M}, 100 \mu \mathrm{m} ; \mathrm{G}, \mathrm{H}, 50 \mu \mathrm{m} ; \mathrm{L}, 200 \mu \mathrm{m}$. 

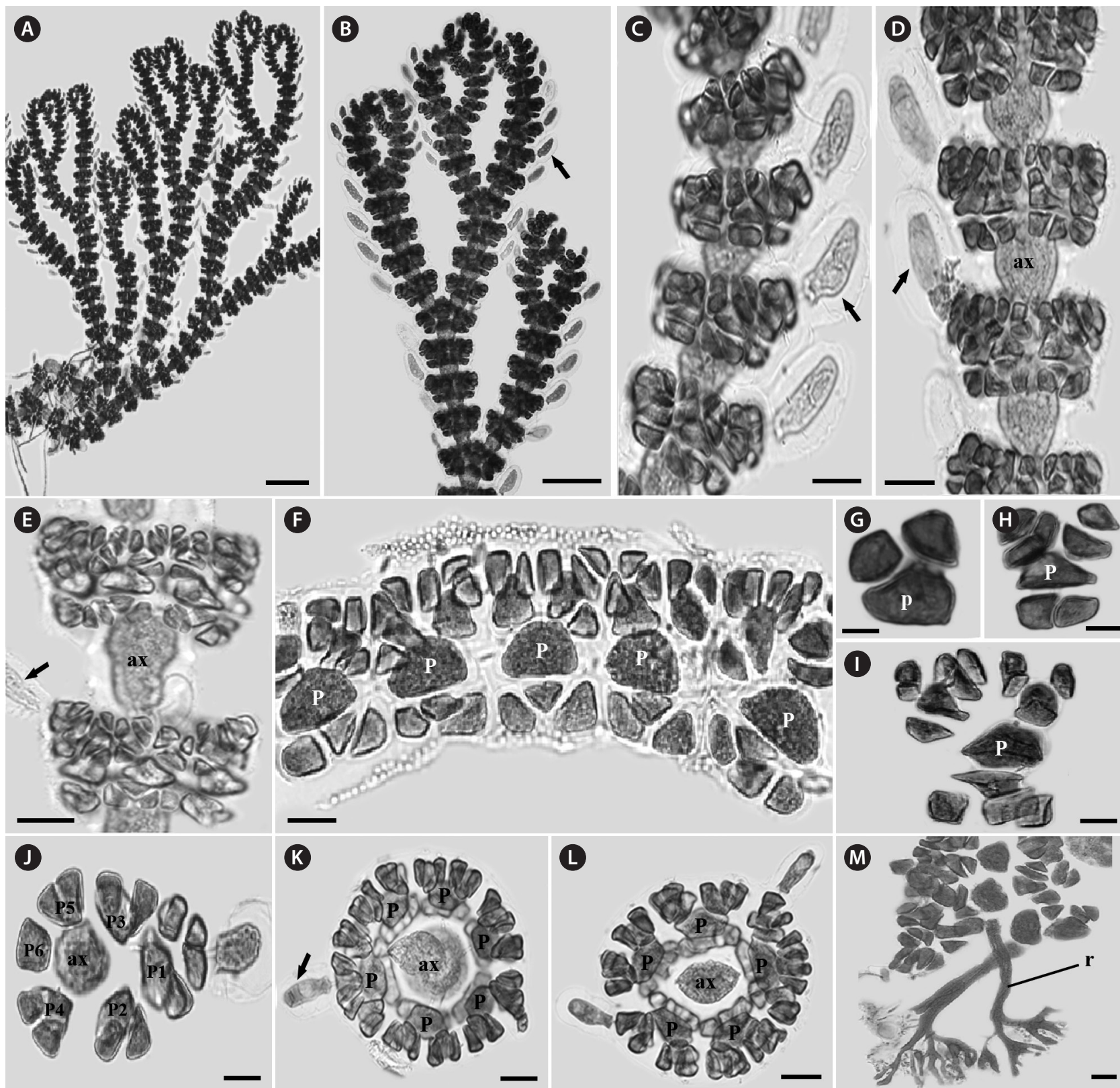

Fig. 3. Gayliella fimbriata from Gampo, Korea. (A) Vegetative plant. (B) Upper part of thallus with gland cells (arrow). (C-E) incomplete cortication of upper (C), middle (D), and lower (E) with gland cells (arrows). (F) Cortitical band with periaxial (p) and cortical cells. (G-I) Developmental series of cortication filaments from periaxial cell (p). (J-L) Cross section views of upper $(J)$, middle $(K)$, and lower $(L)$ thallus showing development of periaxial cells $(p 1-6, p)$. $(M)$ Rhizoid (r). Scale bars represent: A, $200 \mu \mathrm{m} ; \mathrm{B}, 100 \mu \mathrm{m} ; \mathrm{C}-\mathrm{F}, 25 \mu \mathrm{m} ; \mathrm{G}-\mathrm{M}, 20 \mu \mathrm{m}$.

Gayliella fimbriata (Setchell \& N.L. Gardner) T. O. Cho \&

S. M. Boo. (Fig. 3)

Korean name: 깃색동풀(신칭)

Taxonomic position:

Phylum Rhodophyta

Class Florideophyceae

Order Ceramiales

Family Ceramiaceae

\section{Genus Gayliella}

Holotype: Marchant (no. 87a), UC.

Type locality: Eureka, near La Paz, Mexico.

Specimens examined: CUK6119 (Seongsan, Jeju: 23 Jul 2008), CUK6797 (Gampo, Kyeungbuk: 4 Nov 2009).

Habitat: Epiphytic on other algae.

Morphology: Thalli up to $1-2 \mathrm{~cm}$ high, consisting of erect and prostrate axes (Fig. 3A). Branches alternate (Fig. 

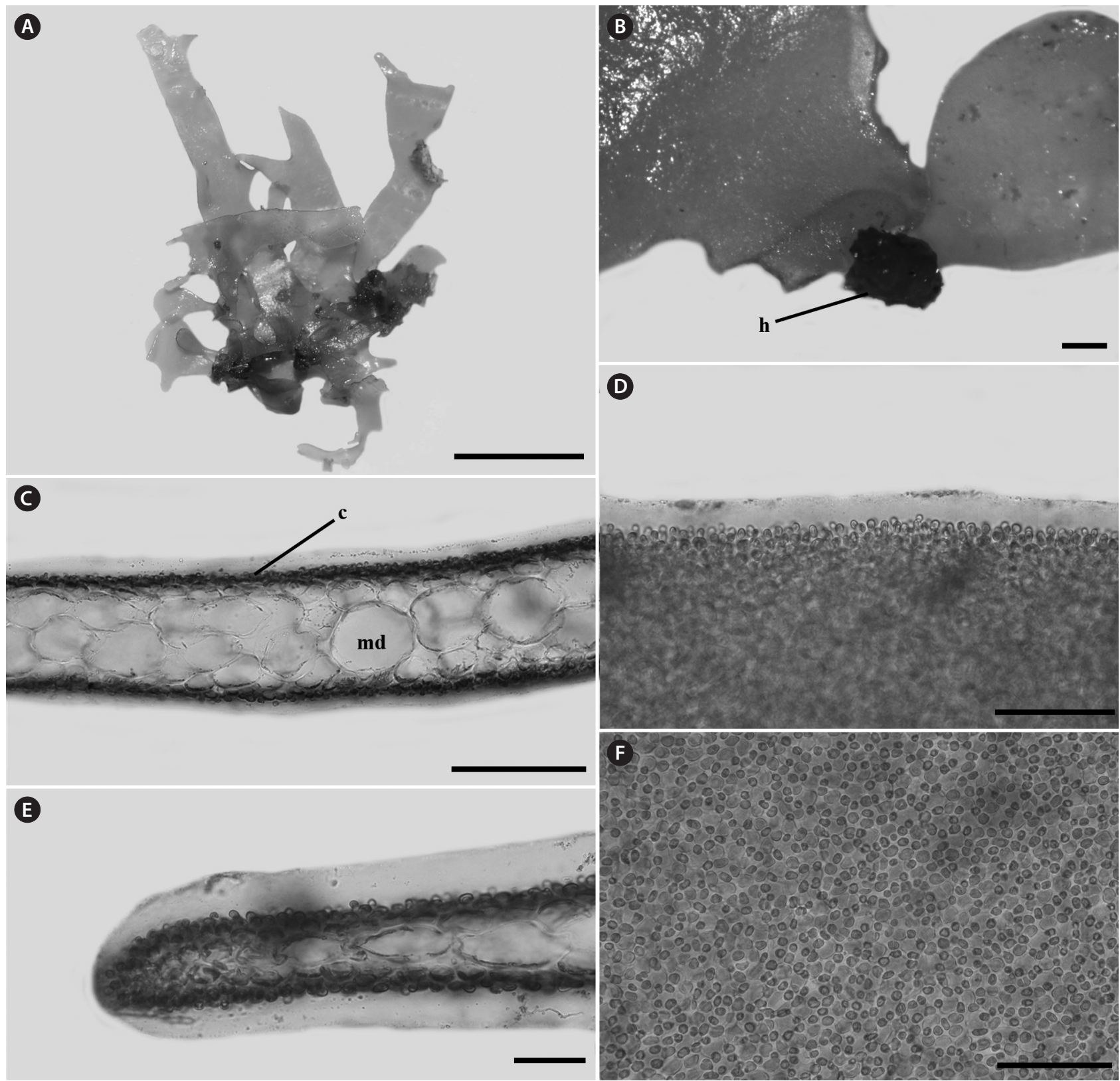

Fig. 4. Leptofauchea rhodymenioides from Juk-do, Ulreng-gun, Korea. (A) Vegetative plant. (B) Details view of small discoid holdfast (h). (C) Cross section view showing cortex (c) and medulla (md). (D) Marginal part of thallus showing gelatinous membrane. (E) Cross section view of marginal thallus. (F) Surface of thallus. Scale bars represent: A, 2cm; B, $539.05 \mu \mathrm{m} ; C-F, 50 \mu \mathrm{m}$.

3A and 3B). Gland cells clavate and developed from cortical cells of acropetal corticating filaments, but rarely basipetal corticating filaments (Fig. 3B-3E). Cortical band composed of three corticating filaments (Fig. 3F-3I). The third cortical initial produced horizontally from periaxial cell (Fig. 3I). Periaxial cells five to seven (Fig. 3J-3L). Rhizoids unicellular with a terminal digitate pad and produced from periaxial cells (Fig. 3M).

Remarks: Gayliella fimbriata was described as Cera- mium fimbriatum from Baja California, Mexico by Setchell and Gardner (1924). Cho et al. (2008) transferred this species into genus Gayliella based on morphological and molecular evidences of the materials collected from Baja California, Mexico. The genus Gayliella was characterized by alternate branching pattern, single basipetal cortical initial produced by horizontal division, and unicellular rhizoids with digitate tips (Cho et al. 2008). Gayliella fimbriata was featured by clavategl and cell, 6-8 periaxial 
cells and wide cortical bands (Cho et al. 2008). Our specimens agree well with $G$. fimbriatum by clavate gland cell although they have 5-7 periaxial cells. We add this species as Gayliella fimbriata in list of Korean algal flora.

\section{Leptofauchea rhodymenioides W. R. Taylor 1942 (Fig. 4)}

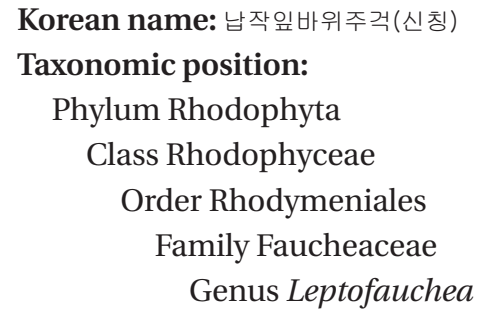

Holotype: Wm. R. Taylor (cystocarpic and tatrsporic), MICH 20253.

Type locality: Aruba Island, Netherlands West Indies.

Specimens examined: CUK9577 (Juk-do of Ulreunggun: 23 Apr 2013).

Habitat: Epiphytic on shells.

Morphology: Thalli 1-2.5 cm high, flat, membranous (Fig. 4A), gelatinous (Fig. 4D), and pink in color. They grow on the shells by small discoid holdfast (Fig. 4B). They expanding with broadly rounded apices and usually dichotomously branched in old plants, and sometimes attached to other blades (Fig. 4A). In surface view, outer cortical cells scattered around inner cortical cells, and the cortical cells loosely arranged (Fig. 4F). Thalli composed of outer cortex and inner medullar layers (Fig. 4C). Outer cortical cells small, rounded, and composed of one cell layers (Fig. 4C). Inner cortical cells rounded to elliptical and composed of 1-2 cell layers. Medullar cells large, polygonal to elliptical, thin-walled, composed of 2-3 cell layers (Fig. 4C). Margins of thallus, cortex and medulla cells close-packed (Fig. 4E). Outer cortical cells scattered around inner cortical cells, and loosely arranged.

Remarks: Leptofauchea rhodymenioides was described from Netherlands by Taylor (1942). It has been reported in North America, Atlantic islands, Caribbean islands, and South America (Díaz-Pulido and Díaz-Ruíz 2003, John et al. 2004, Gavio and Fredericq 2005, Prud'homme van Reine et al. 2005, Taylor 1960, Creed et al. 2010, Wynne 2011). Recently, this species was reported in Japan (Suzuki et al. 2010). It is known as wide distribution in the subtidal zone of warmer seas. According to the original description, this species is characterized by erect with flattened, dichotomously branched fronds, multiaxial thalli, 1-2 cortical cells loosely arranged, 2-3 cell medullar layers with large colourless cells. Of these feature, 2-3 cell layers of medulla appears to be distinct for L. rhodymenioides from other Leptofauchea species (Taylor 1942, 1960, Dalen and Saun- ders 2007, Suzuki et al. 2010). Our collections from Korea agree well with original description of $L$. rhodymenioides.

Sorella pulchra (Yamada) Yoshida \& Mikami 1991: 129, f. 1-11. (Fig. 5)

Korean name: 가지분홍잎사촌(신칭)

Taxonomic position:

Phylum Rhodophyta

Class Florideophyceae

Order Ceramiales

Family Delesseriaceae

Genus Sorella

Holotype: SAP 048988.

Type locality: Hayama, Kanagawa Prov. Japan.

Specimens examined: JN120727-JN12072726 (Dueokdo, Wan-do: 27 Jul 2012); JN120726-1 (Jak-do, Yeosu: 26 Jul 2012).

Habitat: Epilithic on bed rock.

Morphology: Fronds 3-6 cm high and $0.6 \mathrm{~mm}$ wide in the broadest portion, attached to the substratum by discoid holdfast, sometimes forming creeping branch on the basal part. Short branches densely produced by alternately pinnate manner from margins of axial branch in one plane and some of them elongated. The elongated branches produce short branchlets again in the same manners (Fig. 5A and 5B). Fronds cylindrical in the basal part and gradually compressed toward the top of branch having acute apex (Fig. 5C-5E). In the cross-section view of the middle and lower parts of branches, uniserial cells involving an axial cell surrounded by several cortical cell layers. Cortical layers decreasing toward the apical part of branch forming mostly polystromatic frond except apical parts (Fig. 5C-5F). The midrib and microscopic veins inconspicuous. The growth of thalli derived by transverse division of apical cell forming primary cell row, followed longitudinally for secondary cell rows. The secondary cell rows reach the thallus margin, and intercalary cell divisions in each cell row. Some cells in the secondary cell rows cutting off third-order cell rows abaxially (Fig. 5F).

Tetrasporangial sori mostly formed on the upper portion of branchlets and there swollen in both sides of branchlets (Fig. 5G and 5H). The sori consist of two tetrasporangia layers. Mature tetrasporangia $50-60 \mu \mathrm{m}$ in diameter, spherical and divided tetrahedrally (Fig. $5 \mathrm{H}$ ). Procarps scattered in the apical parts of the branches and composed of a supporting cell, a group of sterile cells, and two groups of four-celled carpogonial branches (Fig. 5I and 5J). Mature cystocarps 450-550 $\mu \mathrm{m}$ in diameter and composed of a large branched fusion cell, shortly radiate gonimoblast filaments from the fusion cell, two or three 

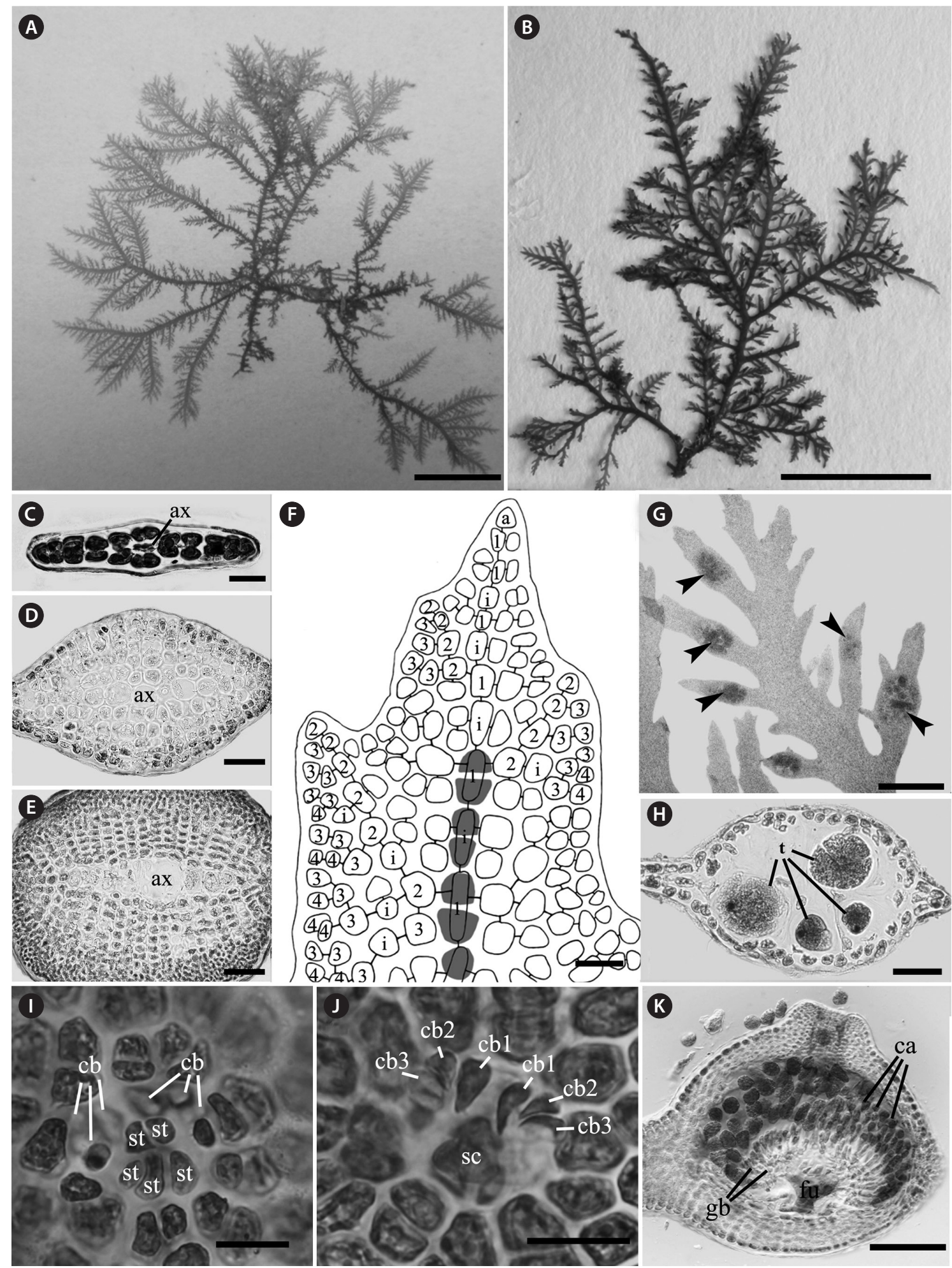

Fig. 5. Sorella pulchra (Yamada) Yoshida \& Mikami. (A) Holotype specimen (SAP048988, photo taken by M. S. Kim) deposited in SAP, Hokkaido, Japan. (B) Tetrasporangial plant from Dueok-do, Wan-do, Korea on 27 July 2012. (C-E) Cross section views of upper (C), middle (D), and lower (E) part of main branch showing an axial cell (ax) surrounded by several cortical cell layers decreasing to upward. (F) Apical part of thallus showing primary (1) to fourth-order (4) cell rows, cells resulting intercalary divisions (i). (G) Tetrasporangial sori (arrow heads) produced on the centers of branchlets. (H) Cross section view of tetrasporangial sori showing two layers of tetrasporangia (t). (l-J) Procarps composed of a supporting cell (sc), a group of sterile cells (st), and two groups of four-celled carpogonial branch (cb). (K) Mature cystocarp composed a large fusion cell (fu), carposporangia (ca) on the terminal of gonimoblasts (gb), 5-8 cells thick pericarp, and an prominent ostiole on apical portion. Scale bars represent: A, B, $1 \mathrm{~cm} ; \mathrm{G}, 500 \mu \mathrm{m} ; \mathrm{D}, \mathrm{E}, \mathrm{K}, 100 \mu \mathrm{m} ; \mathrm{H}, 50 \mu \mathrm{m} ; \mathrm{C}, \mathrm{F}, \mathrm{I}, \mathrm{J}, 20 \mu \mathrm{m}$. 
celled chains of carposporangia on the terminal of each gonimoblasts filament, and 5 to 9 cells thick ostiolate pericarp. Cystocarps hemispherical and more swollen on one side of branches (Fig. 5K).

Remarks: This species was firstly described by Yamada (1938) based on the tetrasporophytes and named Erythroglossum pulchrum Yamada. However, Yoshida and Mikami (1991) observed female gametophytes and confirmed that his specimens have Polyneura-type procarp development (i.e., one group of sterile cells associated with two groups of carpogonial branches) and Sorella-type tetrasporangial position (i.e., the center of branches). According to the results of reproductive characteristics and the position of tetrasporangial sori, they made new combination as Sorella pulchra (Yamada) Yoshida and Mikami.

Recently, we collected this species from two islands (Jak-do, Yeosu and Dueok-do, Wando) on the southern coast of Korea. These specimens were growing on bedrock at $5 \sim 15 \mathrm{~m}$ depth of the subtidal zone. Our morphological observations are well agreed with the description of Yamada (1938) and Yoshida and Mikami (1991). Therefore, we present Sorella pulchra as a new record of Delesseriaceaen species from Korean coast.

\section{ACKNOWLEDGMENTS}

This work was supported by a grant from the National Institute of Biological Resources (NIBR), funded by the Ministry of Environment (MOE) of the Republic of Korea (NIBR No. 2013-01-001). This research was also supported by Basic Science Research Program through the National Research Foundation of Korea (NRF) funded by the Ministry of Education, Science and Technology (NRF2010-0003405) and a grant from Marine Biotechnology Program Funded by Ministry of Oceans and Fisheries of Korean Government to Tae Oh Cho and Ki Wan Nam. Myung Sook Kim and Jeong Chan Kang specially thank the staff of Dadohaesang National Park for supporting transportation and underwater guidance, and the part of financial support was provided by NIBR No. 1834-302 for molecular analyses.

\section{LITERATURE CITED}

Boo SM, Ko YD. 2012. Marine Plants from Korea. Ministry of Land, Transport and Maritime Affairs, Seoul.

Cho TO, Boo SM, Hansen GI. 2001. Structure and reproduction of the genus Ceramium (Ceramiales, Rhodophyta) from Oregon, USA. Phycologia 40: 547-571.

Cho TO, Boo SM, Hommersand MH, Maggs CA, McIvor L, Fredericq S. 2008. Gayliella gen. nov. in the tribe Ceramieae (Ceramiaceae, Rhodophyta) based on molecular and morphological evidence. J Phycol 44: 721-738.

Collins FS. 1889. Ceramium rubrum var. pacificum Collins. In: Phykotheka unversalis, Fasc. VII. No. 302 (Hauck F, P. Richter, eds). E Kummer, Leipzig.

Creed M, Fujii MT, Barreto MBB, Guimarães SMPB, Cassano V, Pereira SMB, Carvalho MFO, Khader S. 2010. Rhodophyceae. In: Catálogo de plantas e fungos do Brasil. Vol. 1. (Forzza RC, ed). Andrea Jakobsson Estúdio; Instituto de Pesquisas Jardim Botânico do Rio de Janeiro, Rio de Janeiro, pp 416-436.

Dalen JL, Saunders GW. 2007. A review of the red algal genus Leptofauchea (Faucheaceae, Rhodymeniales) including a description of L. chiloensis sp. nov. Phycologia 46: 198213.

Díaz-Pulido G, Díaz-Ruíz M. 2003. Diversity of benthic marine algae of the Colombian Atlantic. Biota Colombiana 4: 203-246.

Gavio B, Fredericq S. 2005. New species and new records of offshore members of the Rhodymeniales (Rhodophyta) in the northern Gulf of Mexico. Gulf Mexico Sci 23: 5883.

Harvey WH. 1857. Algae. In: Account of the Botanical specimens. Narrative of the expedition of an American squadron to the China Seas and Japan, performed in the years 1852, 1853 and 1854, under the command of Commodore M.C. Perry, United States Navy. Vol. 2 (Gray A, ed). Government Printer, Washington, DC, pp 331-332.

John DM, Prud'homme van Reine WF, Lawson GW, Kostermans TB, Price JH. 2004. A taxonomic and geographical catalogue of the seaweeds of the western coast of Africa and adjacent islands. Nova Hedwigia Beiheft 127: 1-339.

Kang JW. 1966. On the geographical distribution of marine algae in Korea. Bull Pusan Fish Coll 7: 1-125.

Kylin H. 1925. The marine red algae in the vicinity of the biological station at Friday Harbor, Washington. Lunds Univ Arsskr 21: 1-87.

Lee IK, Kang JW. 1986. A check list of marine algae in Korea. Kor J Phycol 1: 311-325. (in Korean)

Lee YP. 2008. Marine Algae of Jeju. Academy Publishing Co, Seoul. (in Korean)

Lee YP, Kang SY. 2002. A Catalogue of the Seaweeds in Korea. Jeju National University Press, Jeju. (in Korean)

Prud'homme van Reine WF, Haroun RJ, Kostermans LBT. 2005. Checklists on seaweeds in the Atlantic Ocean and in the Cape Verde Archipelago. In: IV Simpósio Fauna e Flora das Ilhas Atlanticas, Praia, 9-13 Setembro 2002. 
Ministério do Ambiente, Agricultura e Pescas, Praia, pp 13-26.

Santelices B. 1989. Algas Marinas de Chile. Distribution, Ecologie, Utilizacion Diversidad. Ediciones Universidad Catolica de Chile, Santiago.

Scagel RF, Garbielson PW, Garbary DJ, Golden L, Hawkes MW, Lindstron SC, Oliveira JC, Widdowson TB. 1989. A Synopsis of Benthic Marine Algae of British Columbia, Southeast Alaska, Washington and Oregon. Phycological Contributions 3. University of British Columbia Press, Vancouver.

Setchell WA, Gardner NL. 1924. The marine algae. Expedition of the California Academy of Sciences to the Gulf of California in 1921. Proc Calif Acad Sci 12: 695-949.

Suzuki M, Hashimoto T, Nakayama T, Yoshizaki M. 2010. Morphology and molecular relationships of Leptofauchea rhodymenioides (Rhodymeniales, Rhodophyta), a new record for Japan. Phycol Res 58: 116-131.

Taylor WR. 1942. Caribbean Marine Algae of the Allan Hancock Expedition, 1939. Allan Hancock Expedition, Report No. 2. University of Southern California Press, Los Angeles.

Taylor WR. 1960. Marine Algae of the Eastern Tropical and
Subtropical Coasts of the Americas. The University of Michigan Press, Ann Arbor.

Woelkerling WJ. 1990. An introduction. In: Biology of the red algae (Cole KM, Sheath RG, eds). Cambridge University Press, Cambridge, pp 1-6.

Wynne MJ. 2011. A checklist of benthic marine algae of the tropical and subtropical western Atlantic: third revision. Nova Hedwigia Beiheft 140: 1-166.

Wynne MJ, Daniels K. 1966. Cumathamnion, a new genus of the Delesseriaceae (Rhodophyta). Phycologia 6: 13-28.

Wynne MJ, Saunders GW. 2012. Taxonomic assessment of North American species of the genera Cumathamnion, Delesseria, Membranoptera and Pantoneura (Delesseriaceae, Rhodophyta) using molecular data. Algae 27: 155-173.

Yoshida T. 1998. Marine algae of Japan. Uchida Rokakuho Publishing Co. Ltd., Tokyo. (in Japanese)

Yamada Y. 1938. Notes on some Japanese algae VIII. Sci Pap Inst Algol Res Fac Hokkaido Univ 2: 124-125, pl. 24. (in Japanese)

Yoshida T, Mikami H. 1991. Sorella pulchra (Yamada) comb. nov., based on Erythroglossum pulchrum Yamada (Delesseriaceae, Rhodophyta). Jpn J Phycol 39: 123-129. 